\title{
PERWAKAFAN TANAH NON HAK MILIK PASCA BERLAKUNYA UNDANG-UNDANG NO. 41 TAHUN 2004
}

\author{
Oleh \\ Anda Setiawati*)
}

Pasca diundangkannya Undang-Undang No. 41 Tahun 2004 tentang Wakaf terjadi perubahan paradigma tanah wakaf. Jika sebelumnya hanya tanah Hak Milik yang dapat diwakafkan, dalam perkembangannya tanah-tanah non Hak Milik juga dapat diwakafkan. Dimungkinkannya tanah non Hak Milik (HGU, HGB, HP di atas tanah negara maupun tanah HGB atau HP di atas tanah HPL atau di atas Hak Milik) untuk jangka waktu tertentu sesuai dengan sisa jangka waktu hak atas tanah yang bersangkutan memunculkan persoalan hukum, dimana ada ketidaksinkronan (inharmonisasi) antara UU wakaf dan peraturan di bidang pertanahan. Dalam perkembangannya, pemerintah melalui instansi terkait menerbitkan peraturan yang mengatur perwakafan tanah non Hak Milik antara lain Peraturan Menteri Agama No. 73 Tahun 2013 tentang Tata Cara Perwakafan Benda Tidak Bergerak Dan Benda Bergerak Selain Uang dan Peraturan Menteri Agraria Dan Tata Ruang/Ka. BPN No. 2 Tahun 2017 tentang Tata Cara Pendaftaran Tanah Wakaf Di Kementerian Agraria Dan Tata Ruang/BPN.

\section{Kata Kunci : Perwakafan Tanah}

\section{A.PENDAHULUAN}

Dari sudut pandang sejarahnya, wakaf banyak dilakukan guna kepentingan umum dan dalam bentuk tempat ibadah, mata air, tanah dan bangunan yang peruntukannya semata-mata bukan untuk kepentingan pribadi. Demikian pula halnya dengan praktek wakaf yang terjadi di Indonesia. Sejarah perkembangan Islam di nusantara memperlihatkan bahwa wakaf tanah banyak digunakan sebagai salah satu cara penyebaran agama Islam yang umumnya digunakan untuk masjid, mushala, dan pesantren. Berdasarkan persetujuan 4 (empat) mashab (Syafi'i, Hambali, Maliki dan Hanafi), wakaf tanah merupakan wakaf yang sifatnya abadi, meskipun dalam ruang lingkup yang luas cakupan wakaf

*) Penulis adalah Dosen Fakultas Hukum Universitas Trisakti meliputi pula harta bergerak seperti wakaf uang. ${ }^{1}$

Setelah berlakunya Undang-Undang No. 5 Tahun 1960 tentang Peraturan Dasar Pokok-pokok Agraria (UUPA), pengaturan wakaf tanah mendapatkan pengaturannya dalam Pasal 49 UUPA. Dalam Pasal 49 ayat (3) UUPA ditegaskan bahwa perwakafan tanah milik dilindungi dan diatur dengan Peraturan Pemerintah. Untuk melaksanakan perintah undangundang tersebut, diterbitkan Peraturan Pemerintah No. 28 Tahun 1977 tentang Perwakafan Tanah Milik. Ketentuan Pasal 1 ayat (1) PP 28/1977 mendefinisikan wakaf sebagai perbuatan hukum seseorang

1 Miftahul Huda, Mengalirkan Manfaat Wakaf Potret Perkembangan Hukum Dan Tata Kelola Wakaf Di Indonesia (Bekasi : Gramata Publishing, 2015), hal. 16. 
atau badan hukum yang memisahkan sebagian dari harta kekayaannya yang berupa "tanah milik" dan melembagakannya untuk selama-lamanya untuk kepentingan peribadatan atau keperluan umum lainnya sesuai dengan ajaran agama Islam.

Menurut doktrin Hukum Tanah Nasional kita, tanah yang dapat diwakafkan terbatas hanya Hak Milik yang memiliki sifat penuh dan bulat (bukan mutlak). Sedangkan hak-hak atas tanah yang lain seperti Hak Guna Usaha (HGU), Hak Guna Bangunan (HGB) dan Hak Pakai tidak dapat diwakafkan karena sifatnya terbatas dan pemegang haknya terikat dengan jangka waktu dan syarat-syarat tertentu. Dengan kata lain karena masalah perwakafan bersifat kekal dan abadi (untuk selama-lamanya), maka hak atas tanah yang berupa HGU, HGB dan Hak Pakai tidak dapat diwakafkan. Artinya tanah yang dapat diwakafkan hanyalah tanah yang berstatus Hak Milik ${ }^{2}$.

Pandangan tersebut sejalan dengan pendapat Boedi Harsono yang menyatakan bahwa berdasarkan ketentuan Pasal 49 UUPA jo Pasal 4 PP 28/1977, tanah yang dapat diwakafkan terbatas hanya tanah Hak Milik, mengingat perbuatan hukum perwakafan tanah merupakan wakaf yang sifatnya abadi dalam artian untuk selama-selamanya. Oleh karena itu, jika yang diwakafkan adalah tanah yang bukan tanah Hak Milik, maka tanah tersebut harus ditingkatkan statusnya menjadi tanah Hak Milik. ${ }^{3}$

2 Taufik Hamami, Perwakafan Tanah Dalam Politik Hukum Agraria Nasional (Jakarta : PT. Tatanusa, 2003), hal. 29.

3 Boedi Harsono, Hukum Agraria Indonesia, Sejarah Pembentukan Undang-Undang Pokok Agraria, Isi Dan Pelaksanaannya, Jilid 1 Hukum Tanah Nasional (Jakarta: Penerbit Universitas Trisakti, 2013), hal. 346.
Dalam perkembangannya hak atas tanah yang diwakafkan diperluas, dimana tidak terbatas hanya pada Hak Milik saja tapi juga non Hak Milik. Sejak UndangUndang No. 41 Tahun 2004 tentang Wakaf jo Peraturan Pemerintah No. 42 Tahun 2006 tentang Pelaksanaan Undang-Undang No. 41 Tahun 2004 tentang Wakaf diberlakukan, hak atas tanah yang dapat diwakafkan meliputi :

a. Hak Milik baik sudah didaftar maupun yang belum didaftar;

b. HGU, HGB atau Hak Pakai di atas tanah Negara;

c. Hak Guna Bangunan atau Hak Pakai di atas Hak Pengelolaan atau Hak Milik; dan

d. HMSRS

Dimungkinkannya tanah non Hak Milik menjadi objek wakaf didasarkan pada konsep wakaf produktif. Pemerintah berupaya meningkatkan peran wakaf sekaligus meningkatkan nilai ekonomi dari tanah wakaf.

Perbedaan pengaturan ini sedikit banyak menimbulkan anggapan bahwa terdapat inharmonisasi antara ketentuan hukum tanah nasional dengan peraturan perundang-undangan yang mengatur tanah wakaf. Tidak bisa dihindari jika pada akhirnya terjadi silang pendapat mengingat perbuatan hukum perwakafan tanah dipahami sebagai wakaf yang sifatnya abadi (untuk selama-selamanya). Untuk itu, perlu dilakukan kajian mendalam guna mencari kejelasan dapat tidaknya tanah non Hak Milik diwakafkan.

\section{B. PEMBAHASAN}

\section{Wakaf Tanah Non Hak Milik}

Adanya pendapat yang mengatakan hanya tanah Hak Milik saja yang dapat diwakafkan tidak bisa dilepaskan dari sejarahnya. Dari sejarah perkembangan Islam di nusantara, ajaran wakaf tanah yang dikembangkan para ulama sesung- 
guhnya dilandasi oleh adanya kebutuhan tempat ibadah seperti masjid, surau atau mushalah sekaligus sebagai cara penyebaran agama Islam. Para ulama termasuk Wali Songo dalam menyebarkan agama Islam mengajarkan bahwa wakaf merupakan sodaqoh jariyah yang tidak akan terputus pahalanya. Pengaruh mazhab Syafi'i yang cukup besar bagi kalangan umat muslim Indonesia juga memperkuat dalil tersebut yang mensyaratkan wakaf untuk selama-lamanya dan bersifat mengikat (luzum) ${ }^{4}$. Karena sifatnya yang luzum) itulah yang kemudian menimbulkan doktrin bahwa hanya tanah Hak milik saja yang paling tepat untuk diwakafkan. Dari beberapa catatan, di abad XX saja tercatat ada 303 lokasi tanah wakaf yang berasal dari tanah hak milik ${ }^{5}$.

Selain dari sudut pandang sejarahnya, pendapat yang mengatakan hanya Hak Milik saja yang dapat diwakafkan juga dipengaruhi oleh pemahaman banyak kalangan tentang definisi wakaf. Wakaf sebagai salah satu bentuk sadaqoh jariyah merupakan tindakan hukum seseorang dengan memisahkan sebagian hartanya dan melembagakannya untuk selama-lamanya untuk kepentingan ibadah dan kepentingan sosial ekonomi lainnya. Artinya, pahala dari wakaf akan selalu mengalir dan selama-lamanya ${ }^{6}$. Sifat kekal dari wakaf juga ditemukan dalam definisi yang diberikan oleh Boedi Harsono yang memaknai wakaf sebagai wakaf sosial yaitu wakaf yang diperuntukan bagi kepentingan peribadatan atau keperluan umum lainnya sesuai dengan ajaran agama Islam. Fungsi dari

4 Rozalinda, Manajemen Wakaf Produktif (Jakarta : PT. RajaGrafindo Persada, 2015), hal. 16-17.

5 Miftahul Huda, Op. Cit, hal. 91-92.

6 Rozalinda, Fiqih Ekonomi Syariah, Prinsip Dan Implementasinya Pada Sektor Kuangan Syariah (Jakarta : RajaGrafindo Persada, 2016), hal. 312-313. wakaf sendiri adalah untuk mengekalkan manfaat tanah yang diwakafkan, sesuai dengan tujuan wakaf yang bersangkutan 7 .

Berbeda dengan definisi wakaf yang terdapat dalam Pasal angka 1 UU Wakaf dan Pasal 1 angka 1 PP Wakaf yang mendefinisikan wakaf sebagai perbuatan hukum wakif untuk memisahkan dan/ atau menyerahkan sebagian harta benda miliknya untuk dimanfaatkan selamanya atau untuk jangka waktu tertentu sesuai dengan kepentingannya guna keperluan ibadah dan/atau kesejahteraan umum menurut Syariah. Berdasarkan pengertian tersebut wakif dapat mewakafkan tanahnya untuk selama-lamanya atau untuk jangka waktu tertentu sesuai dengan hak atas tanahnya. Dengan kata lain, wakaf untuk selama-lamanya berlaku untuk hak atas tanah yang memiliki jangka waktu yang tidak terbatas, sedangkan hak atas tanah yang memiliki jangka waktu terbatas seperti HGU, HGB atau Hak Pakai dapat diwakafkan sesuai sisa jangka hak yang bersangkutan.

Perwakafan tanah yang berasal dari tanah non Hak Milik bisa diterima berdasarkan beberapa aturan perundangundangan yang mengatur tanah wakaf dan secara tersirat mengatur perwakafan tanah non Hak Milik. Pasal 3 dan 4 PP 28/1977 secara tersirat menetapkan bahwa tanah non Hak Milik juga dapat diwakafkan. Dalam Pasal 3 ayat (1) PP 28/1977 disebutkan : "Badan-badan hukum Indonesia dan orang atau orangorang yang telah dewasa dan sehat akalnya serta yang oleh hukum tidak terhalang untuk melakukan perbuatan hukum, atas kehendak sendiri dan tanpa paksaan dari pihak lain, dapat mewakafkan tanah miliknya dengan memperhatikan peraturan perundang-undangan yang berlaku". Sedangkan Pasal 4 PP 28/1997 menyatakan tanah yang dimaksud dalam Pasal 3 harus merupakan

${ }^{7}$ Boedi Harsono, Op. Cit, hal. 345. 
tanah hak milik atau tanah milik yang bebas dari segala pembebanan, ikatan, sitaan, dan perkara.

Peraturan lain yang juga mengatur adalah Surat Edaran Kepala BPN No. 630.1-2782 tahun 1991 tentang Pelaksanaan Pensertifikatan Tanah Wakaf. Dalam surat edaran tersebut dijelaskan bahwa pengertian "tanah milik" adalah semua jenis hak atas tanah yang diatur dalam Pasal 16 UUPA termasuk tanah Negara yang di atasnya terdapat bangunan yang diwakafkan. Berdasarkan pengertian tanah milik yang terdapat pada kedua peraturan tersebut, cukup menjelaskan bahwa tanah milik yang dimaksud tidak terbatas hanya pada tanah Hak Milik saja tapi juga hak-hak atas tanah lainnya. Tapi, inipun masih perlu dilakukan kajian mendalam karena hak atas tanah yang dimaksud oleh Pasal 16 UUPA tidak hanya hak yang primer (yang diberikan oleh negara) tapi juga hak seperti hak sewa, hak membuka tanah, hak memungut hasil hutan dan hak-hak lain yang sifatnya sementara.

Di peraturan perundangan yang lain juga ditemukan pengaturan perwakafan tanah yang berasal dari tanah non Hak Milik yaitu Peraturan Menteri Agama No. 73 Tahun 2013 tentang Tata Cara Perwakafan Benda Tidak Bergerak Dan Benda Bergerak Selain Uang (Permenag 73/2013) dan Peraturan Menteri Agraria Dan Tata Ruang/Ka. BPN No. 2 Tahun 2017 Tentang Tata Cara Pendaftaran Tanah Wakaf Di Kementerian Agraria Dan Tata Ruang/Badan Pertanahan Nasional (Peraturan Ka.BPN No 2/2017). Dalam Pasal 3 Permenag $73 / 2013$ jo Pasal 3 Peraturan Ka.BPN No 2/2017 ditetapkan bahwa tanah yang dapat diwakafkan dapat berupa :

a. Tanah bersertifikat Hak Milik;

b. Tanah bersertifikat HGB, HGU atau HP di atas tanah negara; c. Tanah bersertifikat HGB atau HP di atas tanah HPL atau tanah milik orang lain; dan

d. Tanah negara yang di atasnya berdiri bangunan masjid, mushala dan/atau makam.

Adanya pengaturan tersebut semakin menegaskan bahwa tanah non Hak Milik juga yang dapat diwakafkan. Pengaturan tentang diperbolehkannya tanah non Hak Milik diwakafkan inilah yang kemudian mempengaruhi pemanfaatan tanah wakafnya yang bisa selama-lamanya atau untuk jangka waktu tertentu.

Berbeda dengan tanah Hak Milik yang bisa diwakafkan untuk selama-lamanya, tanah HGB, HGU dan Hak Pakai atas tanah negara maupun HGB atau Hak Pakai di atas tanah HPL atau di atas tanah Hak Milik hanya dapat diwakafkan untuk jangka waktu terbatas. Dibatasinya jangka waktu pemanfaatan tanah wakaf tidak terlepas dari konsep hukum tanah nasional yang mengatur jangka waktu dari masing-masing hak atas tanah. Menurut Maria S.W. Sumardjono, tolok pembeda antara tanah Hak Milik dengan hak atas tanah lainnya adalah pada sifat dan jangka waktunya yang dapat diilustrasikan sebagai berikut ${ }^{8}$ :

\begin{tabular}{|c|c|c|}
\hline 1. & Ciri/sifat & $\begin{array}{l}\text { - Hak Milik adalah } \\
\text { hak yang terkuat, } \\
\text { terpenuh, turun } \\
\text { temurun. } \\
\text { - HGU, HGB, Hak } \\
\text { Pakai secara a- } \\
\text { contratio adalah } \\
\text { hak yang "kurang" } \\
\text { kuat atau } \\
\text { "kurang" penuh. }\end{array}$ \\
\hline 2. & $\begin{array}{l}\text { Jangka } \\
\text { waktu }\end{array}$ & $\begin{array}{l}\text { - Hak Milik tidak } \\
\text { terbatas. } \\
\text { - HGU : } 35 \text { tahun } \\
\end{array}$ \\
\hline
\end{tabular}

8 Maria S.W. Sumardjono, Tanah Dalam Perspektif Hak Ekonomi Sosial Dan Budaya (Jakarta : Kompas, 2008), hal. 147. 


\begin{tabular}{|c|c|c|}
\hline & & $\begin{array}{ll}\text { - } & \text { HGB : } 30 \text { tahun } \\
\text { - Hak Pakai : } 25 \\
\text { tahun } \\
\text { selama } \\
\text { digunakan. }\end{array}$ \\
\hline 3. & Pemanfaatan & $\begin{array}{l}\text { - Hak Milik tidak } \\
\text { dirinci. } \\
\text { - HGU untuk usaha } \\
\text { pertanian, } \\
\text { perkebunan, } \\
\text { perikanan dan } \\
\text { peternakan. } \\
\text { - HGB untuk } \\
\text { mendirikan } \\
\text { bangunan. } \\
\text { - Hak Pakai tidak } \\
\text { dirinci. }\end{array}$ \\
\hline 4. & $\begin{array}{l}\text { Hubungan } \\
\text { dengan } \\
\text { tanahnya }\end{array}$ & $\begin{array}{l}\text { - Hak Milik } \\
\text { hubungan } \\
\text { kepemilikan. } \\
\text { - HGU, HGB, Hak } \\
\text { Pakai : hubungan } \\
\text { pemanfaatan } \\
\text { yaitu } \\
\text { menggunakan } \\
\text { tanah yang bukan } \\
\text { miliknya sendiri. }\end{array}$ \\
\hline
\end{tabular}

Dari ilustrasi tersebut kita dapat memahami mengapa tanah wakaf yang berasal dari tanah non Hak Milik hanya dapat dimanfaatkan untuk jangka waktu tertentu.

Dengan diwakafkannya tanah HGB, HGU maupun Hak Pakai di atas tanah negara (hak yang primer), sejak ikrar wakaf diucapkan hapuslah hubungan hukum antara pemilik tanah dengan tanahnya, dan tanahnya diberi status tanah wakaf. Karena tanah wakaf yang berasal dari tanah HGU, HGB dan Hak Pakai hanya dapat diwakafkan untuk jangka waktu terbatas, dalam pemanfaatanpun juga dibatasi sampai sisa jangka waktu HGU, HGB atau Hak Pakai berakhir. Ketika jangka waktu hak atas tanahnya habis, berakhir pula status tanah wakafnya dan tanahnya menjadi tanah negara. Masalah yang mungkin bisa terjadi adalah jika pemegang HGU, HGB atau Hak Pakai (wakif) mengajukan permohonan perpanjangan haknya. Sebab perpanjangan hak atas tanahnya juga akan mempengaruhi kelanjutan dari status tanah wakafnya. Dari penelusuran yang dilakukan, penulis tidak menemukan penjelasan maupun aturan yang mengatur hal itu.

Ada sedikit perbedaan untuk perwakafan tanah yang berasal dari tanah HGB dan Hak Pakai di atas tanah Hak Milik. Dalam konsep hukum tanah nasional, HGB dan Hak Pakai di atas tanah Hak Milik merupakan hak yang sekunder yang diberikan oleh pemilik tanah Hak Milik atas dasar perjanjian. Akibatnya, jika tanah tersebut hendak diwakafkan, pemanfaatannya hanya untuk jangka waktu tertentu sesuai dengan yang diberikan oleh pemilik tanah. Jika pemegang hak yang sekunder tersebut ingin mewakafkan tanahnya untuk selama-lamanya, undang-undang mensyaratkan adanya izin atau pernyataan pelepasan hak dari pemegang Hak Milik. Namun, pelepasan hak oleh pemilik tanah sepertinya sulit direalisasikan mengingat jangka hak yang dimiliki oleh pemegang Hak Milik tidak terbatas dan yang bersangkutan belum tentu memiliki keinginan untuk melakukan wakaf. Kalaupun ada keinginan yang sama untuk mewakafkan tanah itu, akan lebih baik jika ikrar wakafnya dilakukan secara bersama-sama. Sehingga yang memperoleh pahala tidak hanya pemegang HGB tapi juga pemilik tanah (pemegang Hak Milik).

Untuk perwakafan tanah HGB dan Hak Pakai di atas tanah HPL, harus dipemahami bahwa HPL dalam sistematika hak-hak penguasaan atas tanah bukan merupakan hak-hak atas tanah. Boedi Harsono menyatakan bahwa HPL merupakan gempilan dari hak menguasai 
negara yang dilimpahkan kepada pemegangnya. Dengan demikian jelas sekali bahwa Hak Menguasai dari Negara yang diatur dalam Pasal 2 UUPA sebagai kewenangan di bidang publik, bukan merupakan kewenangan yang ada pada pemegang hak atas tanah yang berada dalam bidang hukum perdata ${ }^{9}$. Pasal 1 Peraturan Pemerintah No. 40 Tahun 1996 mendefinsikan HPL sebagai hak menguasai dari Negara yang kewenangan pelaksanaannya sebagian dilimpahkan kepada pemegang haknya. Pemberian HGB atau Hak Pakai di atas tanah HPL dilakukan atas usulan pemegang HPL yang disampaikan kepada Pejabat BPN.

Menurut Maria S.W Soemardjono seperti dikutip oleh Urip Santoso, dalam perkembangannya ada kecenderungan tanah HPL disejajarkan dengan hak-hak atas tanah yang bersifat perdata 10 . Kecenderungan inilah yang kemudian berdampak pada aspek publik (beheersrecht) dari HPL yang bersifat mengatur bergeser menjadi aspek perdata. Inilah yang mungkin menjadi pengaturan perwakafan tanah HGB atau Hak Pakai di atas tanah HPL. Berdasarkan peraturan perundang-undangan wakaf, pemanfaatan tanah wakaf yang berasal dari tanah HGB dan Hak Pakai di atas tanah HPL hanya diberikan untuk jangka waktu terbatas sesuai dengan sisa jangka waktunya. Dengan berakhirnya jangka waktu hak atas tanahnya, status tanah wakafnya juga berakhir (hapus) dan tanahnya kembali dikuasai oleh pemegang HPL. Jika tanah itu ingin diwakafkan selama-lamanya, pemegang HGB atau Hak Pakai di atas tanah HPL harus dilengkapi dengan pernyataan pelepasan hak dari pemegang HPL.

9 Boedi Harsono, Op. Cit, hal. 277-278.

10 Urip Santoso, Pendaftaran dan Peralihan Hak atas Tanah (Jakarta : Kencana, 2010), hal. 112 .
Mengenai syarat pelepasan hak oleh pemegang HPL, perlu dipahami bahwa pelepasan hak merupakan perbuatan hukum yang mengandung aspek perdata. Pelepasan hak atau pembebasan hak pada dasarnya merupakan salah satu cara memperoleh tanah jika pihak yang memerlukan tanah tidak memenuhi syarat sebagai subjek hak atas tanah. Pelepasan atau pembebasan hak adalah setiap perbuatan untuk melepaskan hubungan hukum antara pemegang hak dengan tanah haknya dengan disertai pemberian imbalan yang disepakati bersama atas dasar musyawarah. Dari pengertian tersebut diketahui pada prinsipnya pembebasan itu pada hakikatnya merupakan suatu perjanjian. Oleh karena itu perbuatan hukum pelepasan hak dikategorikan sebagai perbuatan perdata. Jika pelepasan hak oleh pemegang HPL menjadi syarat untuk tanah $\mathrm{HGB}$ atau Hak Pakai dapat diwakafkan untuk selama-lamanya, hal tersebut menjadi rancu karena kewenangan yang dimiliki oleh pemegang HPL adalah kewenangan yang beraspek publik. Meskipun dalam perkembangan hukumnya terjadi pergeseran, kewenangan memberikan atau menyerahkan bagian-bagian tanah HPL dalam rangka melaksanakan sebagian kewenangan dari negara yang berpedoman pada ketentuan Pasal 2 UUPA.

Persyaratan lain yang harus dipenuhi untuk perwakafan tanah HGU, HGB atau Hak Pakai di atas tanah Negara, tanah HGB atau Hak Pakai di atas HPL atau di atas tanah Hak Milik adalah pernyataan atau keterangan tidak dalam sengketa atau terlibat perkara hukum atau tidak dibebani dengan segala jenis atau dibebani Hak Tanggungan yang diterbitkan oleh instansi yang berwenang berdasarkan peraturan perundang-undangan yang berlaku. Jika tanah-tanah yang akan diwakafkan tersebut masih dalam sengketa atau dibebani Hak Tanggungan, terhadap tanah-tanah tersebut tidak 
dapat dilakukan perbuatan hukum wakafnya.

\section{Tata Cara Perwakafan Tanah Non Hak Milik}

Secara umum, tata cara perwakafan tanah merujuk pada Pasal 9 PP 28/1977 jo Pasal 18 dan 19 Permenag 73/2013. Sama halnya dengan perwakafan tanah Hak Milik, wakaf tanah yang berupa tanah HGU, HGB atau HP di atas tanah negara dan wakaf tanah negara harus dilakukan oleh wakif atau kuasanya di hadapan PPAIW yang dituangkan dalam Akta Ikrar Wakaf (AIW) dan dihadiri oleh 2 (dua) orang saksi. Dalam pembuatan AIW, wajib diserahkan sertipikat hak atas tanah atau tanda bukti pemilikan tanah lainnya. Apabila tanah yang diwakafkan merupakan harta bersama, maka harus ada persetujuan dari suami/istri.

Jika dalam perbuatan hukum wakafnya ternyata belum pernah dibuatkan AIW-nya, sedangkan perbuatan wakafnya sudah terjadi dan wakif sudah meninggal dunia atau tidak diketahui lagi keberadaannya, maka dapat dibuat APAIW dengan syarat ada berbagai petunjuk (garinah), keterangan dari 2 (dua) orang saksi dan/atau keterangan dari Nazhir. Pembuatan APAIW tersebut harus dilakukan atas permohonan masyarakat atau saksi yang mengetahui keberadaan tanah wakaf yang bersangkutan ke Pejabat Pembuat Akta Ikrar Wakaf (PPAIW). Namun, apabila masyarakat atau saksi yang mengetahui perwakafan tanah itu tidak mengajukan permohonan pembuatan APAIW, kepala desa/lurah di mana tanah wakaf itu berada wajib mengajukan permohonan pembuatan APAIW ke PPAIW setempat.

Sebelum dilakukan ikrar wakaf, wakif atau kuasanya harus memenuhi persyaratan administrasi yang paling sedikit memuat :

a. Nama dan identitas wakif;

b. Nama dan identitas nadzir; c. Nama dan identitas petugas pelaksana nadzir, khusus bagi nadzir organisasi/badan hukum;

d. Nama dan identitas saksi;

e. data serta keterangan harta benda wakaf.

Tata cara pembuatan AIW sebagaimana diatur oleh Pasal 34 PP 42/2006 jo Pasal 20 Permenag 73/2013 harus dilaksanakan sesuai dengan peraturan perundang-undangan dan PPAIW wajib meneliti kelengkapan persyaratan administratif perwakafan dan keadaan fisik tanah wakaf. Meskipun persyaratan administratifnya belum lengkap, namun pelaksanaan ikrar wakaf dan pembuatan AIW tetap dianggap sah apabila dilakukan dalam Majelis Ikrar Wakaf yang dihadiri dan ditandatangani oleh Nazhir, Mauquf alaih dan 2 (dua) orang saksi. Dengan selesainya ikrar wakaf, hapuslah hubungan hukum antara tanah HGU, HGB atau Hak Pakai tersebut dengan pemegang haknya.

\section{Pendaftaran Tanah Wakaf Yang Berasal Dari Tanah Non Hak Milik}

Dalam rangka memberikan jaminan kepastian hukum atas tanah yang diwakafkan, pemerintah memerintahkan dilakukannya pendaftaran atas tanah wakaf melalui beberapa ketentuan yaitu :

1. Pasal 19 UUPA;

2. Peraturan Pemerintah No. 24 Tahun 2007 tentang Pendaftaran Tanah;

3. Peraturan Menteri Negara Agraria/Ka. BPN No. 3 Tahun 1997 yang sudah diubah dengan Peraturan Kepala BPN No. 8 Tahun 2012 tentang Perubahan atas Peraturan Menteri Negara Agraria / Ka. BPN No. 3 Tahun 1997 tentang Ketentuan Pelaksana Peraturan Pemerintah No. 24 Tahun 2007 tentang Pendaftaran Tanah; dan

4. Peraturan Menteri Agraria Dan Tata Ruang/ Ka. BPN No. 2 Tahun 2017 tentang Tata Cara Pendaftaran Tanah 
Wakaf Di Kementerian Agraria Dan Tata Ruang/BPN.

Pasal 9 PP 24/1997 secara tegas menetapkan tanah wakaf sebagai salah satu objek pendaftaran tanah. Ditinjau dari sudut pandang objeknya, pendaftaran tanah wakaf merupakan pendaftaran tanah untuk pertama kali, meskipun tanah wakaf sudah pernah didaftar sebelumnya sebagai tanah hak (Hak Milik, HGU, HGB, atau Hak Pakai). Nazhir selaku pengelola tanah wakaf wajib mendaftarkan tanah wakaf tersebut ke Kantor Pertanahan. Untuk bisa didaftar sebagai tanah wakaf, perbuatan hukum perwakafannya harus dibuktikan dengan Akta Ikrar Wakaf (AIW) atau Akta Pengganti Akta Ikrar Wakaf (APAIW).

Menurut peraturan perundangundangan di bidang wakaf yakni Pasal 38 ayat (2) PP 42/2006 jo Pasal 24 ayat (3) Permenag 73/2013, pendaftaran tanah wakaf atas permohonan Nazhir dilakukan dengan melampirkan :

1. sertifikat hak atas tanah atau sertifikat hak milik atas satuan rumah susun yang bersangkutan atau tanda bukti pemilikan tanah lainnya;

2. surat pernyataan dari yang bersangkutan bahwa tanahnya tidak dalam sengketa, perkara, sitaan dan tidak dijaminkan yang diketahui oleh kepala desa atau lurah atau sebutan lain yang setingkat, yang diperkuat oleh camat setempat;

3. izin dari pejabat yang berwenang sesuai ketentuan peraturan perundangundangan dalam hal tanahnya diperoleh dari instansi pemerintah, pemerintah daerah, BUMN/BUMD dan pemerintahan desa atau sebutan lain yang setingkat dengan itu;

4. izin dari pejabat bidang pertanahan apabila dalam sertifikat dan keputusan pemberian haknya diperlukan izin pelepasan/peralihan. Izin pengelolaan atau hak milik dalam hal hak guna bangunan atau hak pakai yang diwakafkan di atas hak pengelolaan atau hak milik;

5. izin dari pemegang hak pengelolaan atau hak milik dalam hal hak guna bangunan atau hak pakai yang diwakafkan di atas hak pengelolaan atau hak milik.

Berdasarkan Pasal 8 Peraturan Menteri ATR/Ka. BPN No. 2/2017, pendaftaran tanah wakaf yang berasal dari tanah HGB, HGU atau Hak Pakai di atas tanah negara harus melampirkan dokumendokumen sebagai berikut :

a. surat permohonan pendaftaran tanahnya;

b. surat ukur;

c. sertipikat HGU, HGB atau Hak Pakai yang bersangkutan;

d. AIW atau APAIW;

e. surat pengesahan Nazhir yang bersangkutan dari instansi yang menyelenggarakan urusan agama tingkat kecamatan; dan

f. surat pernyataan dari Nazhir bahwa tanahnya tidak dalam sengketa, perkara, sita dan tidak dijaminkan.

Demikian pula halnya dengan pendaftaran tanah wakaf yang berasal dari tanah HGB atau Hak Pakai di atas tanah Hak Pengelolaan atau Hak Milik, permohonan pendaftaran tanahnya dilakukan dengan melampirkan :

a. surat permohonan pendaftaran tanahnya;

b. surat ukur;

c. sertipikat HGB atau Hak Pakai yang bersangkutan;

d. AIW atau APAIW;

e. surat izin pelepasan hak dari pemegang Hak Pengelolaan atau Hak Milik;

f. surat pengesahan Nazhir yang bersangkutan dari instansi yang menyelenggarakan urusan agama tingkat kecamatan; dan

g. surat pernyataan dari Nazhir bahwa tanahnya tidak dalam sengketa, perkara, sita dan tidak dijaminkan. 
Setelah prosedur dan mekanisme yang ada dalam Peraturan Menteri ATR/Ka. BPN No. 2/2017 terpenuhi, Kantor Pertanahan akan menerbitkan tanda bukti haknya berupa sertipikat tanah wakaf atas nama Nazhir dan mencatat dalam Buku Tanah dan sertipikat hak atas tanah dengan kalimat :

"Hak atas tanah ini hapus berdasarkan Akta Ikrar Wakaf/Akta Pengganti Akta Ikrar Wakaf tanggal

Nomor ..... dan diterbitkan Sertipikat Tanah Wakaf No. ..../... sesuai Surat Ukur tanggal .... Nomor .... luas ......m²".

Dengan diterbitkannya sertipikat tanah wakaf, hapuslah hak atas tanah yang bersangkutan dan tanahnya berstatus tanah wakaf.

\section{PENUTUP}

Untuk memberikan kejelasan atas perwakafan tanah non Hak Milik, perlu dilakukan harmonisasi pengaturan dari instansi terkait agar tidak menimbulkan persoalan hukum di kemudian hari. Harmonisasi ini perlu dilakukan agar masyarakat yang ingin menjalankan ajaran agamanya tidak memiliki keraguan atau merasa dipersulit oleh ketidakjelasan pengaturan wakaf tanah non Hak Milik.

Dalam pembentukan peraturan teknis di bidang perwakafan tanah diupayakan untuk tidak membuat aturan-aturan yang sifatnya pragmatis. Sinkronisasi dengan peraturan perundang-undangan dalam bidang pertanahan juga harus dilakukan. Hal ini dimaksudkan agar kepastian hukum yang diinginkan dapat tercapai.

\section{DAFTAR PUSTAKA}

Boedi Harsono, Hukum Agraria Indonesia, Sejarah Pembentukan UndangUndang Pokok Agraria, Isi Dan
Pelaksanaannya, Jilid 1 Hukum Tanah Nasional, Jakarta : Penerbit Universitas Trisakti, 2013.

Maria S.W. Sumardjono, Tanah Dalam Perspektif Hak Ekonomi sosial Dan Budaya, Jakarta : Kompas, 2008.

Miftahul Huda, Mengalirkan Manfaat Wakaf Potret Perkembangan Hukum Dan Tata Kelola Wakaf Di Indonesia, Bekasi : Gramata Publishing, 2015.

Rozalinda, Manajemen Wakaf Produktif, Jakarta : PT. RajaGrafindo Persada, 2015.

Fiqih Ekonomi Syariah, Prinsip Dan Implementasinya Pada Sektor Kuangan Syariah, Jakarta : Raja Grafindo Persada, 2016.

Taufik Hamami, Perwakafan Tanah Dalam Politik Hukum Agraria Nasional, Jakarta : PT. Tatanusa, 2003.

Urip Santoso, Pendaftaran dan Peralihan Hak atas Tanah, Jakarta : Kencana, 2010.

Undang-Undang No. 41 Tahun 2004 tentang Wakaf

Undang-Undang No. 5 Tahun 1960 tentang Peraturan Dasar Pokokpokok Agraria

Peraturan Pemerintah No. 42 Tahun 2006 tentang Pelaksanaan UndangUndang No. 41 Tahun 2004 tentang Wakaf

Peraturan Pemerintah No. 28 Tahun 1977 tentang Perwakafan Tanah Milik 
Peraturan Pemerintah No. 24 Tahun 2007 tentang Pendaftaran Tanah

Peraturan Menteri Negara Agraria /Ka. BPN No. 3 Tahun 1997 tentang Ketentuan Pelaksana Peraturan Pemerintah No. 24 Tahun 2007 tentang Pendaftaran Tanah

Peraturan Kepala BPN No. 8 Tahun 2012 tentang Perubahan atas Peraturan Menteri Negara Agraria /Ka. BPN No. 3 Tahun 1997 tentang Ketentuan Pelaksana Peraturan Pemerintah No. 24 Tahun 2007 tentang Pendaftaran Tanah

Peraturan Menteri Agraria Dan Tata Ruang/Ka. BPN No. 2 Tahun 2017 tentang Tata Cara Pendaftaran Tanah Wakaf Di Kementerian Agraria Dan Tata Ruang/BPN

Peraturan Menteri Agama No. 73 Tahun 2013 tentang Tata Cara Perwakafan Benda Tidak Bergerak Dan Benda Bergerak Selain Uang 